\title{
Total Heterotrophic Bacterial Load in the Gut of Detritus Fishes: A Case Study of Pichavaram Mangrove Environment, Southeast Coast, India
}

\author{
V. THANGAMANI and N. RAJENDRAN \\ $P G$ and Research Department of Zoology, \\ Government Arts College, Chidambaram, 608 102, Tamil Nadu, India. \\ http://dx.doi.org/10.12944/CWE.11.3.12
}

(Received: January 12, 2016; Accepted: October 18, 2016)

\begin{abstract}
Total heterotrophic bacterial (THB) load of detritus fin and shell fishes collected from mangrove environment were investigated. The collected fish and prawn samples were subjected to the microbiological study. The THB load was higher in milk fish (Chanos chanos) (2.24 x $\left.10^{5} \mathrm{CFU} / \mathrm{g}\right)$ followed by Indian white prawn (Fenneropenaeus indicus) $\left(3.16 \times 10^{5} \mathrm{CFU} / \mathrm{g}\right)$ than the Liza parsia $\left(1.90 \times 10^{5} \mathrm{CFU} / \mathrm{g}\right)$ and Penaeus monodon $\left(1.88 \times 10^{5} \mathrm{CFU} / \mathrm{g}\right)$. A total of 355 bacterial strains were isolated and identified, in which 64, 57, 51, 47, 44, 42, 21, 29 were belongs to Pseudomonas spp., Aeromonas spp., Bacillus spp., Enterobacter spp., Vibrio spp., Flavobacterium spp., Alcaligenes spp. and Acinetobacter spp., respectively. The present work showed that the Pseudomonas spp. and Aeromonas spp and Bacillus spp., were higher in the gut of fish and prawn samples studied. This work suggests that these bacteria can be effectively used as supplement in fish/prawn feed for commercial aquaculture or as probiotic to enhance the colonization in fish/prawn gut.
\end{abstract}

Keywords: Bacteria, Fishes, Mangroves, Detritus.

\section{INTRODUCTION}

The microorganism enters in to the digestive system of fish through food and environment and certainly not all bacteria in food which gain entry in the digestive tract of fishes establish themselves there ${ }^{1}$. They play an important role in the formation of microbes in the digestive tract of fishes ${ }^{2}$. The digestive tract of fish is rich in nutrient that provides favorable conditions for the growth of majority of bacteria that involved in the digestive process, growth and disease of the host ${ }^{3}$. The composition of intestinal microflora of animals can be altered by age, nutritional condition, developmental stages and stress. These changes can tempt disease or beneficial effect on the host animals ${ }^{4}$. Hence, it may be possible to assess the susceptibility of fish to disease by observing the composition of gut microflora. Some bacteria able to tolerate the low $\mathrm{pH}$ in gastric juices resist the action of bile acids, lysozyme secreted in intestines, immune responses and adheres to the mucus or enteric wall surface could persist for a relatively long time and eventually make intestinal micro flora specific to each host animal ${ }^{5}$. It is clear that bacterial species presents in the gut can influence the health and growth of the host.

The colonization of the microorganisms in the digestive system is influenced by a number of host and non-host related factors in marine and other aquatic animals. On the other hand, bacteria producing antibacterial substances were isolated from marine fish intestines ${ }^{5,6,7}$ thereby suggesting that these bacteria may inhibit the establishment of invading bacteria in the fish intestine. In general, 
due to the bacterial degradation fishes spoil quickly and unfit for consumption. Among the bacteria, Pseudomonas sp. may contribute to spoilage by the production of histamines in fish tissue ${ }^{8}$. The importance of intestinal bacteria has been established in birds and mammals. However, there is limited information is available on the bacterial load in the gut of detritus fishes. Hence, the present study was undertaken to investigate the THB load in the detritus fishes of mangrove environment.

\section{MATERIALS AND METHODS}

Pichavaram mangrove forest is located $\left(11^{\circ}\right.$ $27^{\prime} \mathrm{N} ; 79^{\circ} 47^{\prime} \mathrm{E}$ ) in the south east coast of India nearly $250 \mathrm{Km}$ away from Chennai city and $15 \mathrm{~km}$ away from the Chidambaram town on the eastern side. It is one of the typical mangrove forests in India with a high productivity of 8 tonnes of organic detritus ha/year. It consists of 52 small and large islets with a spread of 1100 ha. Of the total area, $50 \%$ covered by forests, $40 \%$ covered by water and remaining $10 \%$ by sand and mud flats. The biotope is influenced by mixing of neritic water from Bay of Bengal, brackishwater from Coleroon and Vellar estuaries and freshwater from Khan Sahib canal. Thirteen mangrove and 76 of species mangrove associates species are present. The most dominant mangrove plant species of the study area includes Rhizophora and Avicennia.

Detritus fishes, Liza parsia (Golden mullet), Chanos chanos (Milk fish) and shrimps (Indian white prawn - Fenneropenaeus indicus and Tiger prawn Penaeus monodon) were collected during December 2014 from the Pichavaram mangrove waters, in a sterile polythene bags and kept in an ice box at $4^{\circ} \mathrm{C}$. The collected samples were brought to the laboratory immediately for gut micro-floral analysis.

In order to analyse the gut micro floral populations the fish samples were subjected to the surface sterilization by immersion for 30 seconds in $70 \%$ ethanol. The ventral surface of the fish cut open with sterile scissors and then $1 \mathrm{~g}$ of gut content was taken aseptically. The content was homogenized with tissue homogenizer (WW-44468-19, Argos Technologies, China) by adding $1 \mathrm{ml}$ of $50 \%$ sterile sea water and transferred to $9 \mathrm{ml}$ sterile blank solution. In order the enumerate of total heterotrophic bacterial load from gut of fish and prawn samples, the homogenate samples of fish and prawn was serially diluted up to $10^{-5}$ and $0.1 \mathrm{ml}$ of each dilution was spread ('L'-rod method) onto petri dishes containing Zobell Marine Agar 2216 medium (Himedia) which consisted ( $\mathrm{g} / \mathrm{l})$ of Peptic Digest of Animal Tissue (5), Yeast extract (1), Ferric citrate (0.1), Sodium chloride (19.45), Magnesium chloride (8.8), Sodium sulphate (3.24), Calcium chloride (1.8), Potassium chloride (0.55), Sodium bicarbonate (0.16), Potassium bromide (0.08), Stroncium chloride (0.034), Boric acid (0.022), Sodium silicate $(0.004)$, Sodium fluorate (0.0024), Ammonium nitrate (0.0016), Disodium phosphate (0.008), Agar (15), pH (7.6 \pm $0.2)$ and distilled water.

The inoculated plates were incubated (Thermo Scientific Incubator UE-3880000) at $37^{\circ} \mathrm{C}$ for $24 \mathrm{~h}$, after which the colonies developed on the plate were counted and expressed as CFU/g of fish gut (Colony Forming Units). The plates were examined and counted for the number of colonies per Petri dishes. The microbial load in the given sample was calculated using the following formula and it is expressed as Colony Forming Unit (CFU) per gram of the homogenate sample.

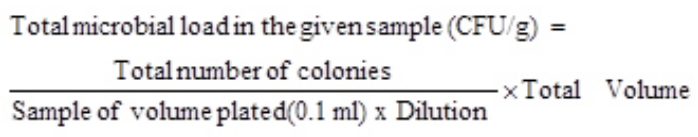

Similarly, the shrimps gut was opened after removing the carapace and the enumeration of THB was carried out as per the procedure adopted for fish samples. Three replicates were maintained for each sample. After three to four days of incubation the bacterial colonies developed on the plates were counted, isolated, purified and preserved in the nutrient agar slants for further analysis. The purified strains were identified up to genus level based on the scheme described by Bergey's ${ }^{9}$. Based on the Gram staining and the morphological characteristics of colony viz., structure, surface, elevation, color, opacity, shape, size, edge and the bacterial colonies were divided into different types and the number of colonies of each recognizable type was counted. Then the pure cultures were obtained through the repeated streaking of the few representatives of each bacterial type. 


\section{RESULTS}

Detritus fishes were studied for their total heterotrophic bacterial load. The results for fin-fishes are given in figure 1. The total heterotrophic bacterial count was high in Milk fish (Chanos chanos) $2.24 \mathrm{x}$ $10^{5} \mathrm{CFU} / \mathrm{g}$ followed by Golden mullet (Lisa parsia) $1.90 \times 10^{5} \mathrm{CFU} / \mathrm{g}$ (Fig.1). The gut bacterial density of shrimps is depicted in figure 2 . The heterotrophic bacterial count was higher in Indian white shrimp (Fenneropenaeus indicus) $3.16 \times 10^{5} \mathrm{CFU} / \mathrm{g}$ than the Tiger prawn (Penaeus monodon) $1.88 \times 10^{5} \mathrm{CFU} / \mathrm{g}$ (Fig.2).

A total of 355 bacterial strains were isolated from the fin-fishes and shell-fishes based on various tests performed and are categorized into eight genera. They are Vibrio (44), Bacillus (51), Pseudomonas (64), Flavobacterium (42), Aeromonas (57), Enterobacter(47), Alcaligenes (21) and Acinetobacter (29) (Table 1).

\section{DISCUSSION}

The numbers and types of bacteria associated with healthy fish are quite natural and interesting. However, the information on the gut micro-flora is generally patchy. In the present study, detritus fishes and shrimps collected from the mangrove waters were analyzed for their total heterotrophic bacteria. In general fishes have close association with environment through which the bacteria are ingested along the food and water.

The bacterial load in the gut of tilapia was high and the reasons may be that the high ambient

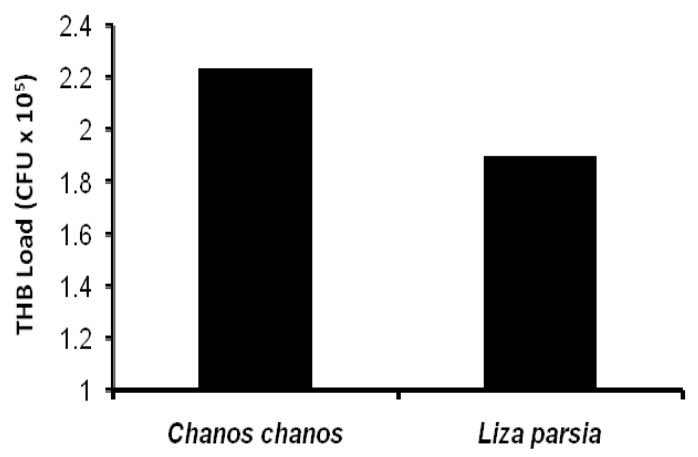

Fig.1: Total heterotrophic bacterial load in the gut of fishes temperature in pond water was close to optimum for many mesophilic bacteria in natural systems ${ }^{10}$. The presence of a high bacterial load in gill and intestine of fish might be due to high metabolic activity of fish associated with increased feeding rates at higher temperature ${ }^{11}$. They also reported that pond water and sediment bacteria influenced the bacterial composition of gills and intestine of tilapia. The bacterial load in the alimentary canal of a fish depends on the quantum and type of food recently ingested ${ }^{12}$. Sakata et $a^{13,14}$ reported that the lower counts obtained are more likely to represent a realistic estimate of the size of aerobic bacterial population attached to, or in intimate association with, the gut epithelium. In Mugil cephalus, maximum luminous bacterial population density was observed in the hindgut and minimum was found in the foregut. In Tachysurus arius, maximum luminous bacterial population density was recorded in the hindgut and minimum was found in the midgut ${ }^{15}$. The intestinal microflora of Salmonid fishes and Tilapia changes with the development ${ }^{16,17}$. MacDonald et a/18 suggested that the decline in bacterial numbers from juvenile to adult fish is an undescribed phenomenon, possibly reflecting subtle differences in the age of the surface with increasing age of the animal.

Several factors, such as bacterial host specificity, food type and water resource may explain these differences ${ }^{19}$. Bacteria in the surrounding environment and feeding habit may have influence on the composition of the gastrointestinal microbiota of fish. The most common bacteria in the gut of marine fishes were Acinetobacter, Vibrio and Pseudomonas $20,21,22$. The Vibrio was considered as one of the predominant bacteria $22,23,24,25$. However,

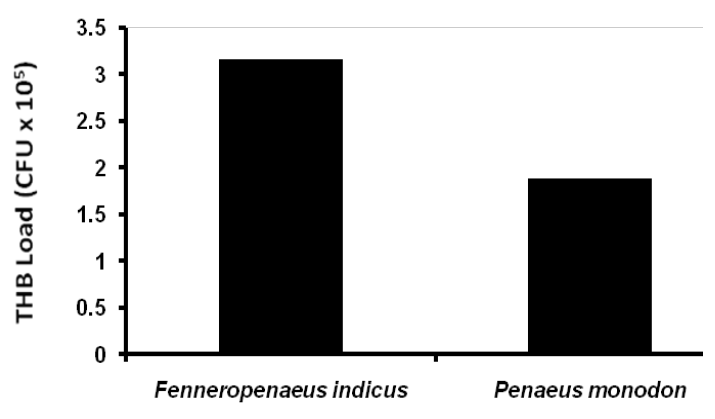

Fig. 2: Total heterotrophic bacterial load in the gut of shrimps 
THANGAMANI \& RAJENDRAN, Curr. World Environ., Vol. 11(3), 778-783 (2016)

Table 1: Bacterial strains isolated from fin- fishes and shell-fishes collected from mangrove waters

\begin{tabular}{lcccc}
\hline Bacterial Genus & $\begin{array}{c}\text { Chanos } \\
\text { chanos }\end{array}$ & $\begin{array}{c}\text { Liza } \\
\text { parsia }\end{array}$ & $\begin{array}{c}\text { Fenneropenaeus } \\
\text { indicus }\end{array}$ & $\begin{array}{c}\text { Penaeus } \\
\text { monodon }\end{array}$ \\
\hline Pseudomonas & 9 & 20 & 16 & $19(64)$ \\
Aeromonas & 11 & 14 & 17 & $15(57)$ \\
Bacillus & 9 & 12 & 13 & $17(51)$ \\
Enterobacter & 11 & 14 & 12 & $10(47)$ \\
Vibrio & 10 & 12 & 13 & $9(44)$ \\
Flavobacterium & 8 & 11 & 10 & $13(42)$ \\
Alcaligenes & 2 & 6 & 8 & $5(21)$ \\
Acinetobacter & 5 & 8 & 10 & $6(29)$ \\
Total & 65 & 97 & 99 & $94(355)$ \\
\hline
\end{tabular}

the number of isolates varied significantly among the species. The gram negative bacteria Aeromonas hydrophila, Aeromonas veronii were the most frequently isolated in the gastro intestinal regions ${ }^{26}$. Intestinal bacterial flora of tilapia Oreochromis mossambicus and optimization of alkaline protease by Virgibacillus pantothenticus was carried out recently ${ }^{27}$. Ringo et $a^{p 8}$ isolated Psychrobacter from the gut of marine fish, such as Arctic charr (Salvelinus alpinus) and Atlantic cod (Gadus morhua) ${ }^{29}$, but its role in the gut of fish is not known. There is no marked difference in the bacterial load in different size groups of tilapia ${ }^{30}$.

In the present study the bacterial strain Pseudomonas sp. was predominant followed by the Aeromonassp. in the gut of all the fishes studied. The THB load was found to be high in milk fish (Fig.1) followed by Indian white prawn and minimum in tiger prawn (Fig.2). The present findings also confirmed the findings of Sivasubramanian et $a^{\beta 0}$ that the
Pseudomonas species is predominant in the gut of tilapia fish. Bacillus has been successfully isolated from the gut of several marine fish and applied as probiotics $^{31,32,33}$. Many Bacillus strains isolated from marine fish could inhibit potential pathogens $\mathrm{s}^{31,33}$. The present work suggest that these bacterial strains can effectively used as supplement in formulated fish/prawn feed or in the form of bacterial biofilm to enhance colonization in the gut. It may also be helpful in developing the probiotic for the commercial aquaculture.

\section{ACKNOWLEDGEMENTS}

We are thankful to The Principal, Govt. Arts College, Chidambaram for providing necessary facilities, Dr. K. Saravanakumar for his help in shaping the manuscript and to UGC, New Delhi for financial support through MRP project [ENVI-201337633].

\section{REFERENCES}

1. Wang, Y.B., J.R. Li and J. Lin, Probiotics in Aquaculture: Challenges and outlook. Aqua., 281: 1-4 (2008).

2. Strom, E. and J.A. Olafsen, The indigenous microflora of wild captured juvenile cod in netpen rearing. In: Lesel R (ed.) Microbiology in Poecilotherms. Elsevier, Amsterdam, 181-185

\author{
(1990). \\ 3. Hansen, G. H., E. Strom and J.A. Olafsen, \\ Effect of different holding regimes on the \\ intestinal microflora of herring (Clupea \\ harengus) larvae. Appl. Environ. Microbiol., \\ 58: 461-470 (1992). \\ 4. Campbell, A.C. and J.A. Buswell, The
}


intestinal microflora of farmed Dover sole (Solea solea) at different stages of fish development. J. Appl. Bacteriol., 55: 215-223 (1983).

5. Olsson, J. C., A. Westerdhal, P. L. Conway and S. Kjelleberg, Intestinal colonization potential of turbot (Scophthalumus maximus) and dap (Limanda limanda)-associated bacteria with inhibitory effects against Vibrio anguillarum. App. Envir. micro., 58: 551-556 (1992).

6. Aiso, K., U. Simidu, K. Hasuo, Microflora in the digestive tract of inshore fish in Japan. J. Gen. Microbiol., 52: 361-364 (1968).

7. Onarheim, A.M. and J. Raa, Characterization and possible biological significance of autochthonous flora in the intestinal mucosa of sea water fish. In: Lesel R (ed) Microbiology in Poecilotherms. Elsevier, Amsterdam (1990).

8. Austin, B, The Bacterial Microflora of Fish, Revised. The Scientific World Journal, 6: 931-945 (2006).

9. Bergey's manual of determinative bacteriology, Williams and Wilkins Co., Baltimore, $9^{\text {th }}$ Edn., MD., pp. 220-229 (1984).

10. Rheinheimer, G., Aquatic microbiology, 3rd ed. University of Kiel, West Germany. John Wiley and Sons, Chichester, New York, Brisbane, Tornoto, p. 257 (1985).

11. Al-Harbi, A.H. and N. Uddin, Bacterial biodiversity of tilapia (Oreochromis niloticus) cultured in brackish water in Saudi Arabia. Aqua., 250: 566-572 (2005).

12. Seki, H., Marine microorganisms associated with the food of young salmon. Appl. Microb., 17: 252-255 (1969).

13. Sakata, T., M. Nakaji, D. Kakimoto, Microflora in the digestive tract of marine fish. I. General characterization of the isolates from yellow tail. Mem. Fac. Fish., 27: 65-71 (1978).

14. Sakata, T., J. Okabayashi, D. Kakimoto, Variation in the intestinal microflora of Tilapia reared in fresh water and seawater. Bull. Jpn. Soc. Sci. Fish., 46(3): 313-317 (1980).

15. Ramesh, A. and V.K. Venugopalan, Role of luminous bacteria in chitin degradation in the intestine of fish. MIRCEN-J. Appl. Microbiol. Biotecnol., : 55-59 (1989).

16. Yoshimizu, M., T. Kimura and M. Sakai, Microflora of the embryo and fry of salmonids.
Bull. Jpn. Soc Sci. Fish., 46: 967-975 (1980).

17. Sugita, H., Y. Ishida, Y.Deguchi and H. Kadota, Aerobic microflora attached to the wall surface in the gastro-intestine of Tilapia nilotica. Bull. Coll. Agric. Vet. Med. Nihon Univ., 3: 302-306 (1982).

18. MacDonald, N.L., J.R. Stark and B. Austin, Bacterial microflora in the gastrointestinal tract of Dover sole (Solea solea L.), with emphasis on the possible role of bacteria in the nutrition of the host. FEMS Microbiol. Lett., 35: 107-111 (1986).

19. Verner-Jeffreys, D.W., R.J. Shields, I.R. Bricknell and T.H. Birkbeck, Changes in the gut associated micro-flora during the development of Atlantic halibut (Hippoglossus hippoglossus $L$.) larvae in three British hatcheries. Aqua., 219: 21-42 (2003).

20. Cahill, M. M., Bacterial flora of Fishes: A review. Micro. Eco., 19; 21-41 (1990).

21. Gatesoupe, F.J., J.L.Z. Infante, C. Cahu, and P. Quazuguel, Early weaning of sea bass larvae, Dicentrarchus labrax: the effect on microbiota, with particular attention to iron supply and exo-enzymes. Aqua., 158: 117-127 (1997).

22. Munro, P.D., A. Barbour and T.H. Birkbeck, Comparison of the gut bacterial flora of start-feeding larval turbot reared under different conditions. J. App.Bact., 77: 560-566 (1994).

23. Olafsen, J.A., Interactions between fish larvae and bacteria in marine aquaculture. Aqua., 200: 223-247 (2001).

24. Sugita, H., and Y. Ito, Identification of intestinal bac-teria from Japanese flounder (Paralichthys olivaceus) and their ability to digest chitin. Lett. Appl. Micro., 43: 336-342 (2006).

25. Eddy, S.D., and S.H. Jones, Microbiology of summer flounder Paralichthys dentatus fingerling production at a marine fish Hatchery. Aqua., 211: 9-28 (2002).

26. Molinari, L.M., D.O. Scoaris, R.B. Pedroso, N.L.R. Bittencourt, C.V. Nakamura, T. UedaNakamura, B.A.A. Filho, and B.P.D. Filho, Bacterial microflora in the gastrointestinal tract of Nile tilapia, Oreochochromis niloticus, cultured in a semi-intensive system. Acta Scie. Biol. Sci., 25: 267-271 (2003). 
27. Thillaimaharani, K. A., A. R. Logesh, K. Sharmila, B. Kaja Magdoom and M. Kalaiselvam, Studies on the intestinal bacterial flora of tilapia Oreochromis mossambicus and optimization of alkaline protease by Virgibacillus pantothenticus. J.Micro. Antimicrob., 4(5): 79-87 (2012).

28. Ringo, E., S. Sperstad, R. Myklebust, T.M. Mayhew and R.E. Olsen, The effect of dietary insulin on aerobic bacteria associated with hindgut of Arctic charr (Salvelinus alpinus L.). Aqua. Res., 37: 891-897 (2006a).

29. Ringo, E., Sperstad, S., Myklebust, R., Refstie, S., and Krogdahl, A., Characterisation of the microbiota as-sociated with intestine of Atlantic cod (Gadus morhua L.) The effect of fish meal, standard soybeanmeal and a biopro-cessed soybean meal. Aqua, 261: 829-841 (2006b).
30. Sivasubramanian, K., S. Ravichandran and R. Kavitha, Isolation and Characterization of Gut Micro Biota from Some Estuarine Fishes. Mar. Sci., 2(2): 1-6 (2012).

31. Kennedy, S.B., J.W. Tucker, C.L. Neidic, G.K. Vermeer, V.R. Cooper, J.L. Jarrell and D.G. Sennett, Bacterial management strategies for stock enhancement of warm water marine fish: a case study with common snook (Centropomus undecimalis). Bull. Mar. Sci., 62: 573-588 (1998).

32. Velmurugan, S. and S. Rajagopal, Beneficial uses of probiotics in mass scale production of marine ornamental fish. Afr. J. Micro. Res., 3: 185-190 (2009).

33. Sugita, H., Y. Hirose, N. Matsuo and Y. Deguchi, Production of the antibacterial substance by Bacillus sp. strain NM 12, an intestinal bacterium of Japanese coastal fish. Aquac., 165: 269-280 (1998). 